\title{
Links between the Southern Oscillation Index and Hydrological Hazards on a Tropical Pacific Island ${ }^{1}$
}

\author{
Fames P. Terry, ${ }^{2}$ Rishi Raj, ${ }^{3}$ and Ray A. Kostaschuk ${ }^{4}$
}

\begin{abstract}
River floods and hydrological droughts (low stream water resources) are a recurrent problem in different parts of Fiji, causing disruption and hardship for many rural communities. These extremes in fluvial behavior are associated with large seasonal variability in rainfall, generated by intense tropical storms in the wet season and prolonged rain failure in the dry season. Such conditions are linked to the influence of El Niño/Southern Oscillation (ENSO) in the Southwest Pacific. The Southern Oscillation Index (SOI) is the climatic measure of the strength of ENSO activities and shows good correspondence with (1) tropical cyclone flood magnitude and (2) critically low stream discharges after a 2-month time lag, in two of Fiji's main river systems. If ENSO conditions become more frequent or sustained in the future as some climate models suggest, then the SOI will be a useful tool for projecting in advance the severity of hydrological hazards, which can assist in disaster mitigation and management.
\end{abstract}

ON The INTERANnual timescale, the El Niño/Southern Oscillation (ENSO) is our planet's most powerful climatic phenomenon (Hilton 1998). At intervals of about 5-7 yr, there is a disturbance in the Walker atmospheric circulation over the Pacific Ocean and a weakening of the southeast trade winds. This causes a large pool of warm ocean water usually centered around New Guinea to surge eastward across the equatorial Pacific (Congbin Fu et al. 1986). This disturbance to the Pacific Ocean and atmospheric system, called El Niño, lasts for more than a year and brings droughts, prolonged wet conditions,

I Financial support provided by the University of the South Pacific and the Natural Sciences and Engineering Research Council of Canada. Manuscript accepted 13 October 2000.

${ }^{2}$ Department of Geography, University of the South Pacific, Suva, Fiji (fax: +679 301 487; E-mail: terry j@usp.ac.fi).

${ }^{3}$ Hydrology Section, Public Works Department, P.O. Box 3740, Samabula, Fiji (E-mail: rishi@is.com.fj).

${ }^{4}$ Department of Geography, University of Guelph, Ontario, N1G 2W1, Canada (E-mail: rkostasc@ uoguelph.ca).

Pacific Science (2001), vol. 55, no. 3:275-283

(C) 2001 by University of Hawai'i Press

All rights reserved and a high incidence of storms to different parts of the tropical Pacific. As sea surface temperatures rise off the western coast of the Americas, a tongue of warm water stretches back along the equator. Rainfall becomes abundant in this new low-pressure region, whereas the western Pacific suffers rainfall failure and drought. The strength of ENSO activity is expressed as the Southern Oscillation Index (SOI), which is a measure of monthly atmospheric pressure differences between Tahiti and Darwin (see Ropelewski and Jones 1987, Allan et al. 1991).

\section{ENSO and Stream Bebavior}

ENSO clearly has the potential to affect stream behavior in a major way through its influence on Pacific-wide climatic patterns. In recent years there has been a concerted focus in hydrological studies to explore possible links between ENSO and various aspects of river flow, including seasonality and extremes (e.g., Moss et al. 1994, Chiew et al. 1998, Waylen and Laporte 1999). Indications have emerged in Costa Rica, eastern Australia, New Zealand, and parts of the Pacific U.S. mainland that valid relationships between stream flow and SOI, or other ENSO measures such as sea surface temperatures, can be 
established (Kahya and Dracup 1993, Moss et al. 1994, Cayan et al. 1999, Krasovskaia et al. 1999).

For the Fiji Islands in the tropical Southwest Pacific, the most extreme high and low river flows (i.e., floods and droughts [here drought refers to hydrological drought: diminished stream water resources after prolonged no or low rainfall]) are linked to the response of island fluvial systems to ENSOinduced tropical cyclones and periods of prolonged rain failure and are serious hydrological hazards because of their impacts on the physical and human environment. These impacts include channel erosion and siltation, destruction of property, damage to agriculture (threatening food security), and risks to human life and health (R.R., J.P.T., and J. Rokovada, 1998, paper presented to the 27th Annual Conference of the South Pacific Applied Geoscience Commission, Suva, Fiji; Terry and Raj 1999). Such impacts place a difficult socioeconomic burden on our resource-limited island nation: the costs to the Fiji Government of the 1997-1998 drought and 1999 floods amounted to F\$100 million and F\$40 million, respectively. Improved mitigation and management of hydrological hazards is therefore a priority in Fiji, but this requires a better understanding of the links between these hazards and ENSO than currently exists.

The aim of this study therefore was to examine the relationship between the strength of the ENSO signal measured by the SOI and the magnitude of extreme high and low discharges in rivers on the main island of Fiji. The potential use of the SOI as a predictor for hydrological hazards in the future was then considered.

\section{Fiji Climate and ENSO Influences}

Fiji's main island Viti Levu (Figure 1) is a mountainous volcanic island $17.5^{\circ}$ south of the equator in the Southwest Pacific. The tropical latitude and influence of the nearby warm Southern Equatorial Ocean Current gives Viti Levu a wet/dry tropical climate. A clear geographical distribution in rainfall is observed. The southeast side of the island faces the predominant trade winds and therefore receives much more precipitation than the northwest side, which is rain-shadowed by interior highlands reaching elevations over $1300 \mathrm{~m}$.

The climate is distinctly seasonal. The typical wet season extends from November to April and the dry season from May to October. Tropical cyclones are a common feature of the wet months. From 1970 to 2000,40 cyclones traversed Fiji island waters. These severe storms often produce extreme rainfalls, especially over the interior of Viti Levu because the volcanic mountains force orographic lifting of the spiraling rain bands. Cyclone Gavin in March 1997, for example, produced a deluge. The highest-elevation weather station at $760 \mathrm{~m}$ received a maximum 24-hr rainfall of $610 \mathrm{~mm}$, at $10-\mathrm{min}$ intensities reaching $150 \mathrm{~mm} / \mathrm{hr}$ (Terry and Raj 1999). Widespread soil saturation and rapid surface and subsurface runoff cause a high degree of hydrological short-circuiting. Rivers respond with rapid and very large increases in discharge, and dangerous overbank floods are the result.

In the dry season, an uneven distribution of rain days and prolonged lack of moisture can occur. Rainfall seasonality is more pronounced for the island's leeward northwest region, which receives only $20 \%$ of the annual total in the dry months, compared with $33 \%$ for the windward side (Terry and Raj 1998). Rivers in the northwest may experience very low stream baseflows as a result, which represents a severe depletion of available water resources because the rural population depends mainly on surface water for domestic needs and watering livestock (Terry and Raj in press). Human suffering and economic hardship are the result.

In years without strong ENSO activity, Fiji's rainfall benefits from convection along the low-pressure South Pacific Convergence Zone (SPCZ) that extends diagonally from near the Solomon Islands, across to Samoa, the Cook Islands, and beyond (Salinger et al. 1995). At the start of El Niño events, convective storms and tropical cyclones affecting the islands are generated as the eastwardmigrating pool of warm sea surface tem- 


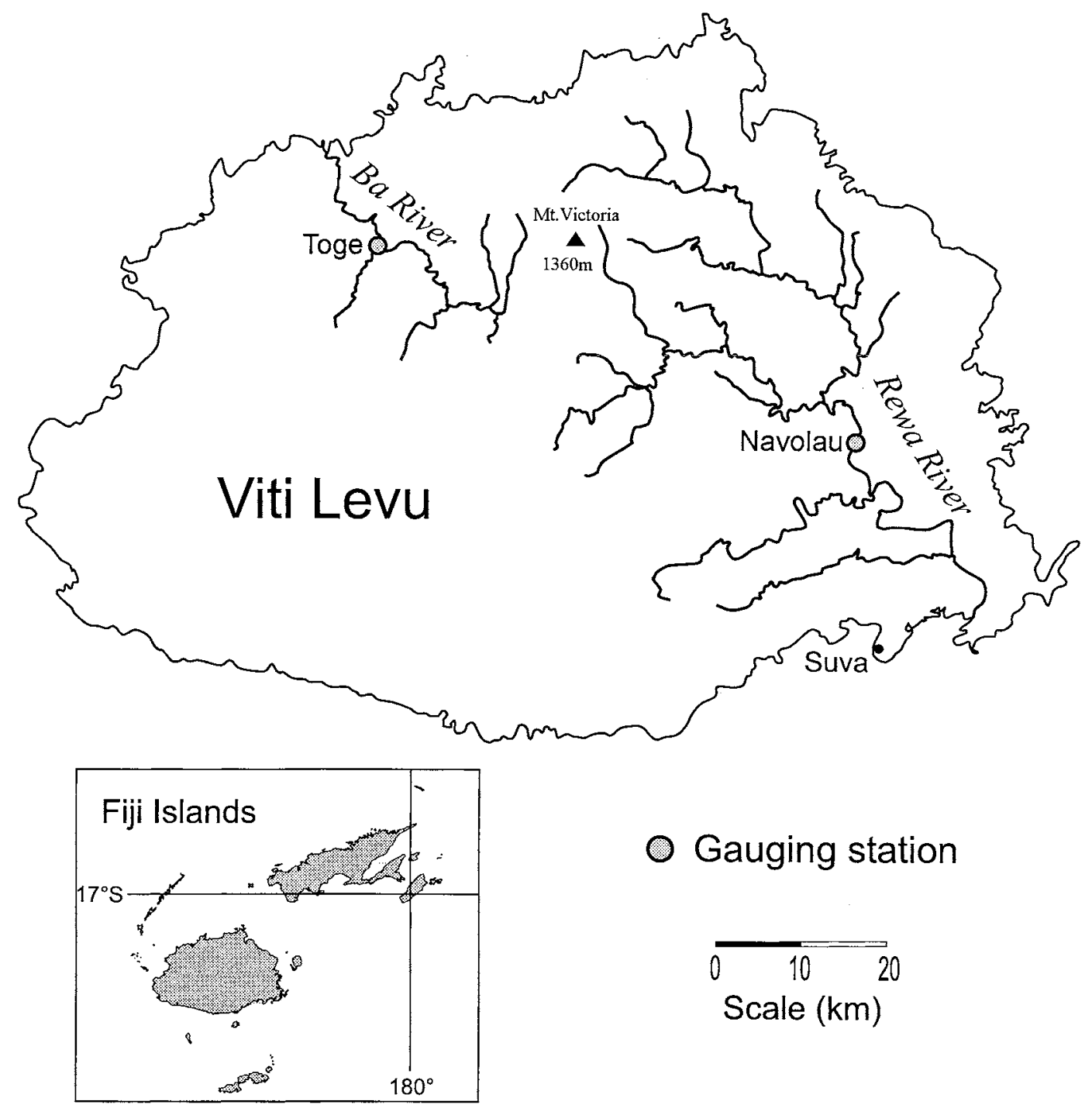

Figure 1. Location of the Rewa and Ba Rivers on Viti Levu island, Fiji.

peratures passes across northern Fiji waters. Then, as El Niño conditions develop fully, an equatorward shift in the SPCZ (Hay et al. 1993, Vincent 1994) away from the Fiji group leads to prolonged dry conditions. The exceptional El Niño of 1997-1998 was a good example of the variability in climatic and hydrological impacts in Fiji. The event began with a succession of severe tropical cyclones: Gavin in March 1997 and June in May 1997.
Both produced damaging floods in many places (Terry and Raj 1999). The floods were then followed by one of the worst droughts to afflict Fiji this century (Fiji Meteorological Service 1998). Rain failed across successive dry seasons and the intervening wet season (when precipitation is normally reliable), and river flows reached record lows (Public Works Department, Hydrology Section, unpubl. river flow records). 


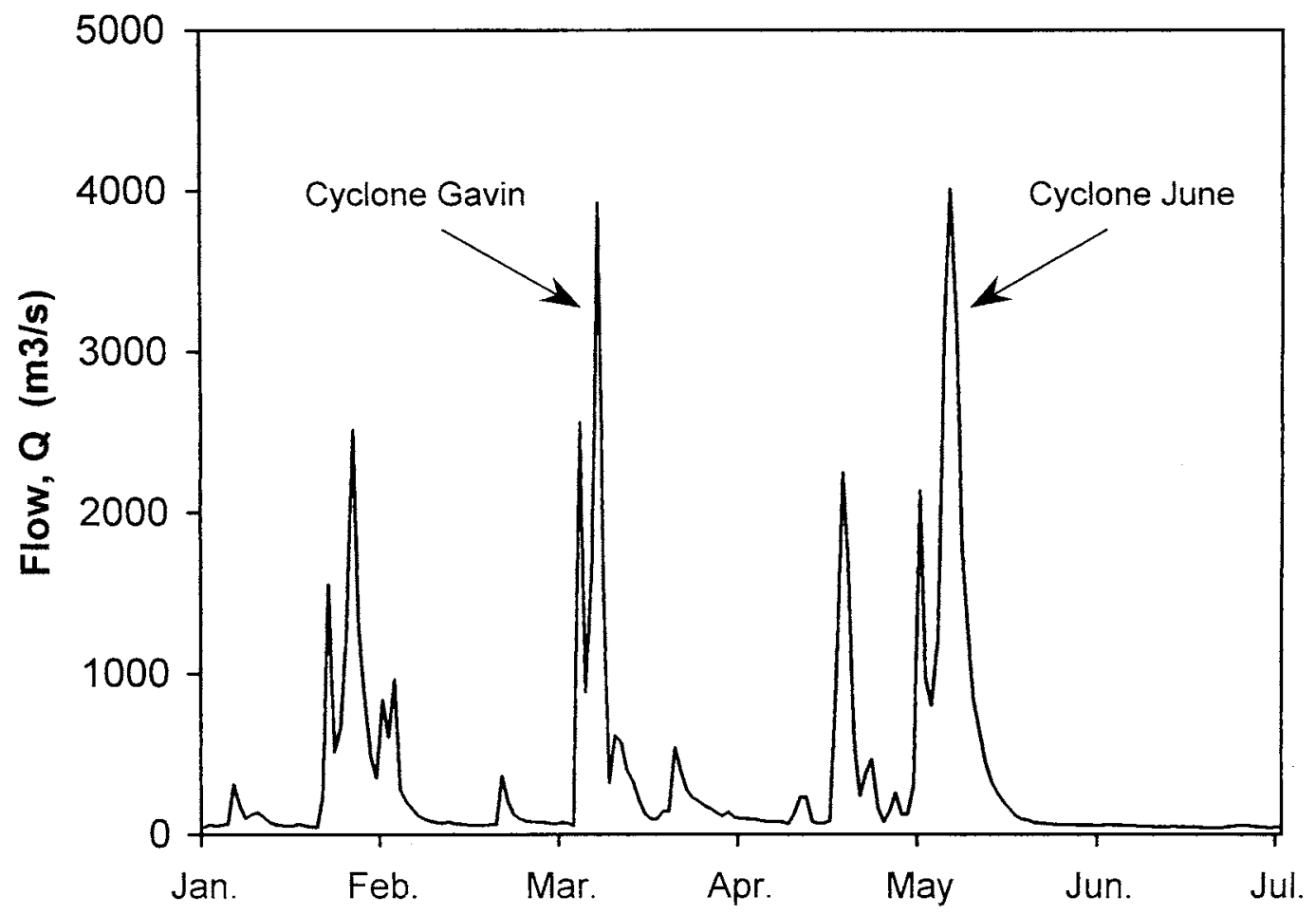

FIgURE 2. Hydrograph for the Rewa River at Navolau during tropical cyclones Gavin and June in 1997.

\section{MATERIALS AND METHODS}

In this study, correlation analysis was used to examine the relationship between SOI and extreme river behavior on Viti Levu. SOI data were obtained from the Fiji Meteorological Service. The Rewa and Ba Rivers (Figure 1) were selected for investigation because of the availability of reliable long-term flow records from hydrological gauging stations operated by the Hydrology Section of the Public Works Department, and because these are the main rivers on the wet (windward) and dry (leeward) sides of the island. Topography is steep and rugged in the upper parts of both study basins, which rise to $1360 \mathrm{~m}$ at the Mount Victoria divide, but becomes more hilly nearer the coast.

The Rewa River in the wet zone has the largest drainage basin, covering $2900 \mathrm{~km}^{2}$. Vegetation is mostly dense rain forest, with subsistence cultivation of root crops and cattle pasturing on floodplains and adjacent slopes. It also has a recorded history of major floods caused by tropical cyclones: flooding has occurred 15 times during tropical cyclones between 1970 and 2000 (i.e., one flood every $2 \mathrm{yr}$ on average), and the fluvial system can be described as a flood-dominated regime. The river hydrograph in Figure 2 illustrates the characteristics of the highmagnitude flood peaks produced by tropical cyclones Gavin and June at the start of the 1997-1998 El Niño.

In earlier work we (Kostaschuk et al. in press) found that tropical cyclones occur more often in Fiji waters when the SOI is negative, due to the influence of the Southern Oscillation on the usual spatial distribution of cyclone origin, with more storms spawned farther to the north and east (closer to Fiji) during EI Niños (Revell and Goulter 1986, Basher and Zheng 1995). However, cyclone frequency in Fiji waters did not show a good link to temporal patterns in the SOI. Here, therefore, we compare flood peak magnitude 


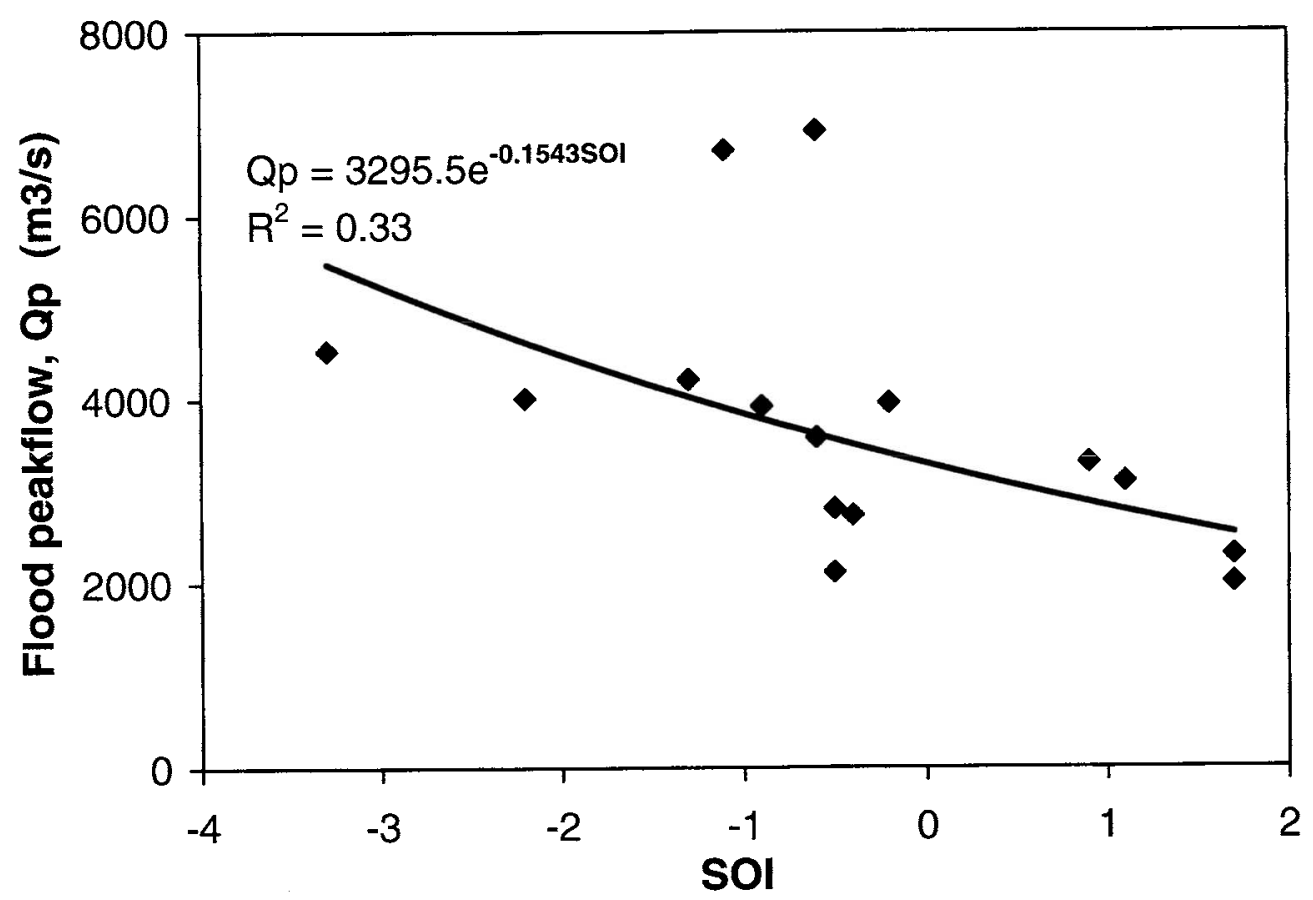

FIgURE 3. Peak flood discharge $(Q)$ in the Rewa River at Navolau during tropical cyclones versus SOI for the month that the cyclone occurred.

(rather than timing) produced by tropical cyclones in the Rewa River with the SOI (Figure 3).

The Ba River in the north of Viti Levu is Fiii's third largest river system, covering 930 $\mathrm{km}^{2}$. It is the most important river in the dry zone, but experiences very low baseflows in periods of drought. Savanna grassland vegetates the steep highland terrain, whereas the more gentle coastal slopes are widely used for growing sugarcane. Figure 4 compares temporal patterns in the SOI with mean discharge $(Q)$ in the Ba River.

\section{RESULTS}

For the Rewa River, Figure 3 indicates that peak river discharge produced by tropical cyclones is negatively related to the strength of the SOI (i.e., tropical cyclones that occur during El Niño events are more likely to produce larger floods). A curve-fitting exercise showed that an exponential regression curve has the best fit to the data $(r=-0.57$, $P>0.05$, Table 1). For the analysis of low flows in the Ba River, difficulties arise when comparing SOI and monthly means of discharge because of the large influence of seasonality on river behavior. Thus, poor correlations were derived between SOI versus monthly $Q(r=0.17)$, prior 3-month mean of SOI versus monthly $Q(r=0.21)$, SOI versus $Q$ for the month with the lowest flow each year $(r=0.18)$, and lowest monthly SOI in year versus lowest monthly $Q$ in year $(r=0.23)$. However, once flow seasonality is removed by plotting 13-month running means, low flow trends in the Ba River show good correspondence with El Niño events, although lagging behind by approximately 2 months $(r=0.73, P>0.001$, Figure 5).

\section{DISCUSSION}

Despite the fact that it remains difficult to predict the occurrence of tropical cyclones 


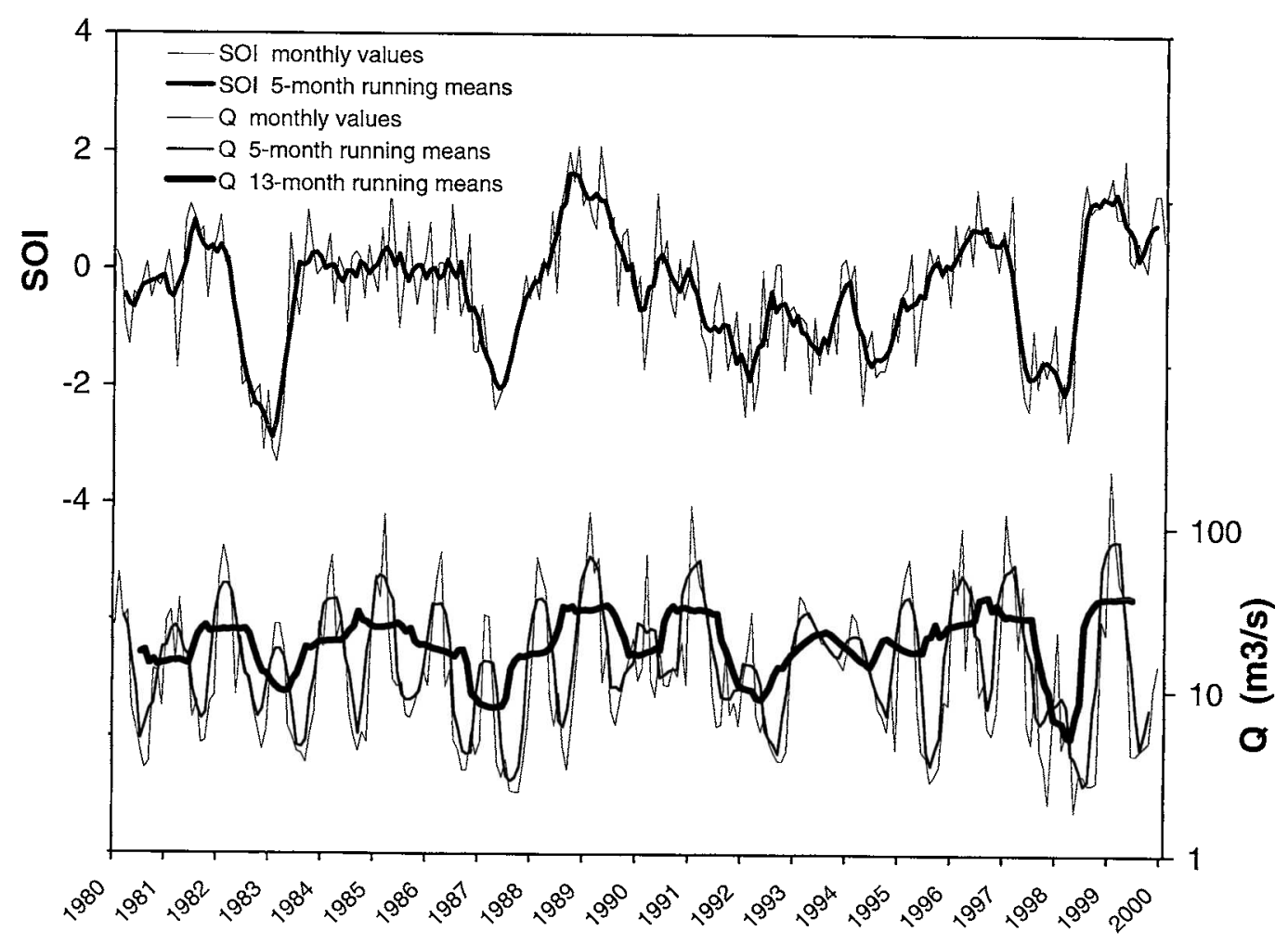

Figure 4. A comparison of the temporal patterns in SOI and Ba River flow (Q) behavior at Toge, 1980-2000.

TABLE 1

SOI Relationship with Peak Flood Discharge in the Rewa River

\begin{tabular}{lcr}
\hline \hline Regression Curve Type & Equation & Correlation \\
\hline Linear & $Q=-531.94 \mathrm{SOI}+3529.70$ & $r=-0.49$ \\
Polynomial & $Q=-129.33 \mathrm{SOI}^{2}-670.03 \mathrm{SOI}+3719.7$ & $r=-0.54$ \\
Exponential & $Q=3295.50 \mathrm{e}^{-0.1545 \mathrm{I}}$ & $r=-0.57$ \\
\hline
\end{tabular}

near the Fiji Islands (as it does elsewhere), our work suggests that the strength of the SOI at the time of future storms can give some warning of the size of the flood in the Rewa River, which has the largest and most populated river basin in Fiji. Because tropical cyclones rarely develop very close to Fiji, but instead tend to generate nearer the equator and then approach on a southerly track over 2 or 3 days, this delay will be useful in alerting vulnerable sections of the rural community who live on low-lying areas near floodplains in advance of the expected flood wave. This is important because in the future floods may become more severe due to increasing tropical cyclone intensity in the Pacific region if the climate changes toward more sustained El Niño-like conditions, as many climate scientists now predict (see Holland 1997, Trenberth and Hoar 1997, Timmermann 


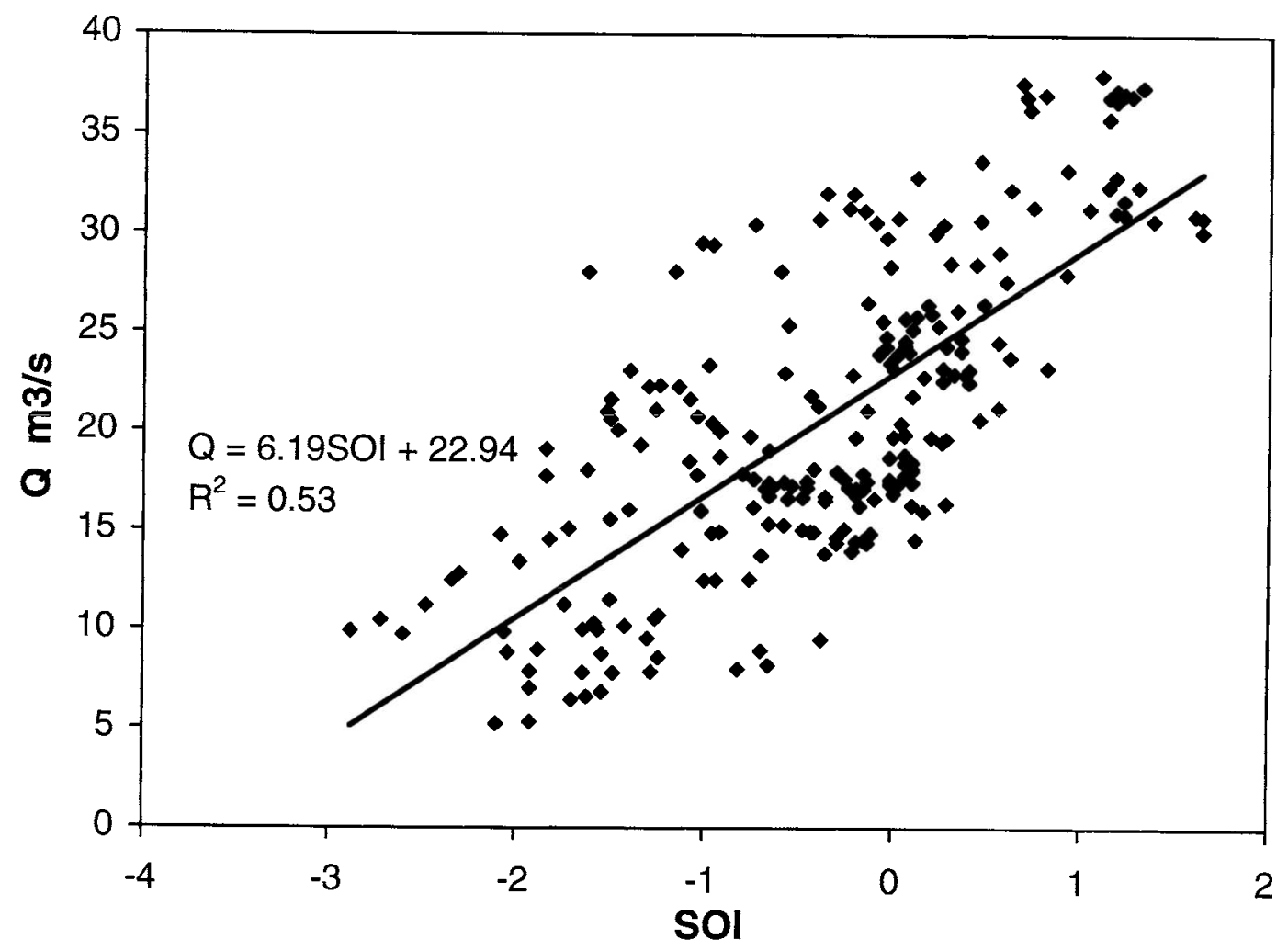

Figure 5. Correlation between 13-month running means of Ba River flow $(Q)$ and 5-month running means of SOI with a 2 -month lag.

et al. 1999; P. Whetton, R. Jones, K. Hennessy, R. Suppiah, K. Walsh, and W. Cai, 2000 , paper presented to the Pacific Islands Climate Change Conference, Rarotonga, Cook Islands). In this scenario, projections of the likely flood hazard magnitude shall become more crucial for the success of disaster reduction programs in Fiji.

For future droughts that are related to the ENSO phenomenon (rather than random dry years), forecasts of the depletion of surface water resources in the $\mathrm{Ba}$ River can be made with a high degree of confidence 2 months ahead on the basis of SOI values. The Ba River has the largest catchment in the drought-prone northwest of Viti Levu and supports a substantial population of sugarcane farmers. Such forecasts will be valuable for government planning of alternative water supply (e.g., carting by truck) before resource scarcity becomes critical. Elsewhere in Fiji's dry zone, there may be different lag times between low SOI and low river baseflow. This needs to be investigated so that projected stream water resources in times of rain failure can be assessed on a catchment-bycatchment basis.

\section{ACKNOWLEDGMENTS}

The Fiji Meteorological Service is thanked for providing the SOI record. This paper was originally presented to the Pacific Islands Conference on Climate Change, Climate Variability, and Sea-Level Rise, organized by the South Pacific Regional Environmental Programme, 17-21 April 2000, Rarotonga, Cook Islands. The Department for Inter- 
national Development of the British Government provided generous funding through the University of the South Pacific for J.P.T. to attend this meeting. The written paper was prepared while J.P.T. visited the University of Sydney School of Geosciences and thanks are extended to several colleagues there for their constructive comments on the work. Two referees also provided useful suggestions on the original manuscript.

\section{Literature Cited}

Allan, R. J., N. Nicholls, P. D. Jones, and I. J. Butterworth. 1991. A further extension of the Tahiti-Darwin SOI, early ENSO events and Darwin pressure. J. Clim. 4:743-749.

Basher, R. E., and X. Zheng. 1995. Tropical cyclones in the Southwest Pacific: Spatial patterns and relationships to Southern Oscillation and sea surface temperature. J. Clim. 8:1249-1260.

Cayan, D. R., K. T. Redmond, and L. G. Riddle. 1999. ENSO and hydrologic extremes in the western United States. J. Clim. 12:2881-2983.

Chiew, F. H. S., T. C. Piechota, J. A. Dracup, and T. A. McMahon. 1998. El Niñol Southern Oscillation and Australian rainfall, streamflow and drought: Links and potential for forecasting. J. Hydrol. 204: 138-149.

Congbin Fu, H. F. Diaz, and J. O. Fletcher. 1986. Characteristics of the response of the sea surface temperature in the central Pacific associated with warm episodes of the Southern Oscillation. Mon. Weather Rev. 114:1716-1738.

Fiji Meteorological Service. 1998. Annual weather summary. Climatological Division, Nadi Airport, Fiji.

Hay, J., J. Salinger, B. Fitzharris, and R. Basher. 1993. Climatological seesaws in the Southwest Pacific. Weather Clim. 13:9-21.

Hilton, A. C. 1998. The influence of $\mathrm{El}$ Niño-Southern Oscillation (ENSO) on frequency and distribution of weatherrelated disasters in the Pacific islands region. Pages 57-71 in J. P. Terry, ed. Climate and environmental change in the
Pacific. School of Social and Economic Development, University of the South Pacific, Suva, Fiji.

Holland, G. J. 1997. The maximum potential intensity of tropical cyclones. J. Atmos. Sci. 54:2519-2541.

Kahya, E., and J. A. Dracup. 1993. U.S. streamflow patterns in relation to the $\mathrm{El}$ Niño/Southern Oscillation. Water Resour. Res. 29:2491-2503.

Kostaschuk, R., J. Terry, and R. Raj. The impact of tropical cyclones on river floods in Fiji. Hydrol. Sci. J. (in press).

Krasovskaia, I., L. Gottschalk, A. Rodrídguez, and S. Laporte. 1999. Dependence of the frequency and magnitude of extreme floods in Costa Rica on the Southern Oscillation Index. Pages 81-89 in L. Gottschalk, J.-C. Olivry, and D. Reed, eds. Hydrological extremes: Understanding, predicting, mitigating. International Association of Hydrological Sciences. Publication 255.

Moss, M. E., C. P. Pearson, and A. I. McKerchar. 1994 The Southern Oscillation index as a predictor of the probability of low streamflows in New Zealand. Water Resour. Res. 30:2717-2723.

Revell, C. G., and S. W. Goulter. 1986. South Pacific tropical cyclones and the Southern Oscillation. Mon. Weather Rev. 114:1138-1145.

Ropelewski, C. F., and P. D. Jones. 1987. An extension of the 'Tahiti-Darwin Southern Oscillation Index. Mon. Weather Rev. 115:2161-2165.

Salinger, M. J., R. E. Basher, B. B. Fitzharris, J. E. Hay, P. D. Jones, J. P. MacVeigh, and I. Schmidely-Leleu. 1995. Climate trends in the south-west Pacific. Int. J. Climatol. 15:285-302.

Terry, J. P., and R. Raj. 1998. Hydrological drought in western Fiji and the contribution of tropical cyclones. Pages 73-85 in J. P. Terry, ed. Climate and environmental change in the Pacific. School of Social and Economic Development, University of the South Pacific, Suva, Fiji.

. 1999. Island environment and landscape responses to 1997 tropical cyclones in Fiji. Pac. Sci. 53:257-272. 
The 1997-98 El Niño and drought in the Fiji Islands. In J. Gladwell, ed. Hydrology and water management in the humid Tropics: Hydrological research issues and strategies for water management. UNESCO-IHP (in press).

Timmermann, A., J. Oberhuber, A. Bacher, M. Esch, M. Latif, and E. Roeckner. 1999. Increased El Niño frequency in a climate model forced by future greenhouse warming. Nature (Lond.) 398:694-697.
Trenberth, K., and T. J. Hoar. 1997. El Niño and climate change. Geophys. Res. Lett. 24:3057-3060.

Vincent, D. G. 1994. The South Pacific Convergence Zone (SPCZ): A review. Mon. Weather Rev. 112:1949-1970.

Waylen, P., and M. S. Laporte. 1999. Flooding and the El Niño-Southern Oscillation phenomenon along the Pacific coast of Costa Rica. Hydrol. Processes 13:26232638. 